\title{
Effects of platelet-rich plasma gel on skin healing in surgical wound in horses ${ }^{1}$
}

\author{
Efeitos do gel de plasma rico em plaquetas na cicatrização de feridas cirúrgicas na pele de \\ cavalos
}

\author{
Rafael DeRossi', Anna Carolina Anciliero de Oliveira Coelho" ${ }^{\mathrm{II}}$, Gisele Silveira de Mello" ${ }^{\mathrm{II}}$, Fabrício Oliveira Frazílio" ${ }^{\mathrm{II}}$, Cássia \\ Rejane Brito Leal ${ }^{\mathrm{IV}}$, Gilberto Gonçalves Faccov ${ }^{\mathrm{V}}$, Karine Bonucielli Brum ${ }^{\mathrm{VI}}$
}

\author{
I PhD, Associate Professor, Department of Veterinary Medicine, Surgery and Anesthesiology, Faculty of Veterinary Medicine and Animal Science, \\ UFMS, Mato Grosso do Sul, Brazil. \\ ${ }^{\text {II }} \mathrm{MD}$, Veterinarian, Brazil. \\ III Master, Assistant Professor, Division of Surgery, University for Development of the State and the Pantanal Region (UNIDERP), Brazil. \\ ${ }^{\text {IV }}$ Fellow PhD Degree, Post-graduate in Health and Development, West Central Region (UFMS), Mato Grosso do Sul, Brazil. \\ ${ }^{v}$ Master, Assistant Professor, Division of Pathology, UNIDERP, Brazil. \\ Iv PhD, Associate Professor, Department of Pathology, UFMS, Mato Grosso do Sul, Brazil.
}

\begin{abstract}
Purpose: To establish a low-cost method to prepare platelet-rich plasma (PRP) and evaluates the potential of platelet derived factors to enhance wound healing in the surgical wounds in equine. Methods: To obtain a PRP gel, calcium gluconate and autologous thrombin were added to platelet-rich plasma. For the tests six saddle horses were used and two surgical incisions were made in each animal. Wounds were treated with PRP gel or untreated. Sequential wound biopsies collected at Treatment 1: at days 5 and 30 and Treatment 2: at days 15 and 45 post wounding permitted comparison of differentiation markers and wound repair. Results: The optimal platelets enrichment over 4.0 time's baseline values was obtained using $300 \mathrm{~g}$ for $10 \mathrm{~min}$ on the first centrifugation and $640 \mathrm{~g}$ for $10 \mathrm{~min}$ on the second centrifugation. Conclusion: Wounds treated with PRP gel exhibit more rapid epithelial differentiation and enhanced organization of dermal collagen compared to controls in equine
\end{abstract}

Key words: Platelet-Rich Plasma. Wound Healing. Skin. Horses.

\section{RESUMO}

Objetivo: Estabelecer um método econômico na preparação de plasma rico em plaquetas (PRP) e avaliar se os fatores derivados destas plaquetas aceleram a cicatrização de feridas cirúrgicas em cavalos. Métodos: Gluconato de cálcio e trombina autógena foram adicionados ao PRP para a obtenção do gel de PRP. Foram usados seis cavalos de sela, cada um dos quais sofreu duas incisões cirúrgicas. Uma destas incisões foi tratada com gel de PRP e a outra suturada de maneira tradicional (controle). A biópsia das feridas foi coletada de maneira seqüencial; Tratamento 1. nos dias 5 e 30 e Tratamento 2. nos dias 15 e 45 do período pós-operatório permitindo uma comparação na diferenciação epitelial e no reparo das feridas. Resultados: O enriquecimento das plaquetas obtido através de uma primeira centrifugação usando 300 g por 10 minutos e uma segunda 640 g por 10 minutos acelerou quatro vezes a reparação tecidual em relação ao controle. Conclusão: As feridas tratadas com gel de PRP apresentaram uma mais rápida diferenciação epitelial e acelerou a organização do colágeno da derme comparado ao grupo controle em cavalos.

Descritores: Plasma Rico em Plaquetas. Cicatrização de Feridas. Pele. Cavalos.

${ }^{1}$ Research performed at Postgraduate Program in Health and Development, West Central Region, Federal University of Mato Grosso do Sul (UFMS), Brazil.

\section{Introduction}

The skin healing is the aim of studies and researches due to its clinical, scientific and economic interest, especially due to the great frequency of wounds caused by injury in horses. The wound's healing is a physiological phenomenon that initiates from the loss of integrity of the skin generating a solution of continuity that reaches the underlying layers in diverse degrees and depends on a series of chemical reactions classically divided in four phases: inflammation, debridation, reparation and maturation ${ }^{1-2}$.

In equine the healing of surgical or traumatic wounds delay and many times the cost limits the success of the healed wound. For this reasons, successful cutaneous wound healing needs combination drug therapy. A rich source of the complex group 
of growth factors (GF's) essential to natural wound repair is the platelet $^{3}$. The platelets act in the haemostasis; wound healing and reepithelialization liberating diverse GF's that stimulate the angiogenesis, promoting growth and vascular fibroblast proliferation that in turn provide an increase in the collagen synthesis $^{4-5}$. Platelet-rich plasma (PRP) is $100 \%$ biocompatible and safe. It poses absolutely no infectious risk to the patient because it is made from the patient's own plasma.

The PRP gel is obtained through the addition of calcium gluconate plus thrombin to the plasma. Degranulation of platelets by proteins such as thrombin causes them to release these factors which include transforming growth factor- $\beta$ (TGF- $\beta$ ), fibrinogen, platelet-derived growth factor (PDGF), epidermal growth factor (EGF), transforming growth factor- $\alpha$ (TGF- $\alpha$ ), vascular endothelial growth factor (VEGF), platelet thrombo-plastin, thrombospondin, coagulation factors, calcium, serotonin, histamine, and hydrolytic enzymes ${ }^{6}$.

Several factors influence the healing process after traumatic or surgical injury, like advanced age, malnutrition and diseases such as diabetes. Wounds below the hock or knee in the horse are resistant to healing being a problem even in the healthiest animals ${ }^{7}$. However, this difficulty does not occurs in the upper body heal frequently. This may be due to the large distance between the trunk and lower limbs providing tissues of the lower limbs with a poor blood supply, thus lower oxygen, a lower temperature and an imbalance of growth factors ${ }^{7}$. Research with associated therapies in the healing treatment in the equine upper body may be helpful in improving the knowledge of the healing process in wounds below the hock or knee in this species.

GF's are essential for regulating the cellular events involved in wound healing 8 . Several clinical studies demonstrate that GF treatment accelerates healing of normal tissues and promotes healing of impaired wounds ${ }^{9}$. TGF- $\beta$ is particularly important because once it is activated it affects most aspects of tissue repair, including initiation and termination in the treatment of chronic, nonhealing or slow to heal wounds over a decade ago ${ }^{8}$. Based in these reasons, we hypothesized that surgical wounds in horses treated with PRP gel would exhibit enhanced wound repair compared to control tissues. The objective of this study was to establish a protocol of the PRP gel from horse whole blood, growth factors, and autogenous thrombin, and also to do the first comments with the application of the PRP gel in surgical wound healing in sequentially sampled biopsies in horses.

\section{Methods}

All procedures were approved by the Ethics Committee of the Federal University of Mato Grosso do Sul. Six adults of saddle bred horse (two females and four males) in good general health weighing between $380-460 \mathrm{~kg}$ and aged 3-15 years were used in this study. All the animals were maintained at the Faculty of Veterinary Medicine facilities throughout the experiment. The horses were sedated by intravenous administration of $0.08 \mathrm{mg} / \mathrm{kg}$ of romifidine $(0.8 \mathrm{ml} / 100 \mathrm{~kg}$ body weight; Sedivet, BoehringerIngelheim). The hair on selected areas, lateral left neck, was shaved and the sites were prepared for sterile surgery. Local anesthetic, $2 \%$ lidocaine $(5-7 \mathrm{ml})$ was infiltrated in the sites of the incisions. Two full-thickness excisional skin wounds were created in each horse and separated from each other by a $6 \mathrm{~cm}$ 's space. Each $8 \mathrm{~cm}$ full-thickness skin wound was dissected it free from the underlying subcutaneous tissue with a scissor ( $1 \mathrm{~cm}$ in both sides). The wounds were placed in a vertical column. One of two treatments was randomly assigned to each wound in each animal: (1) no treatment other than wound and closed in a simple interrupted pattern with 2.0 nylon and (2) application of PRP gel in the subcutaneous tissue and the wound closed in a simple interrupted pattern with 2.0 nylon. The wounds were bandaged with sterile nonadherent and with semi occlusive gauze. The use of prophylactic systemic antibiotics was done and the horses remained in hygienic stable and exercise limited. The horses were kept under close observation for several hours after the wounds and checked at regular intervals thereafter for the first week for early detection of any complication.

For biopsy collection, the horses were divided in two groups: (1) surgical biopsy punch at days 5 (G1D5) and 30 (G1D30) after creation of the wounds and (2) surgical biopsy punch at days 15 (G2D15) and 45 (G2D45) after creation of the wounds. Each group was composed by three horses. All horses were sedated before the procedures; the biopsy sites were cleaned with saline solution and gauze. Full-thickness specimens were collected using an 8-mm surgical biopsy punch. The biopsy were performed at the both wound margins and included a 3 - to $4 \mathrm{~mm}$ region of uninjured skin and 4-to $5 \mathrm{~mm}$ depth in the subcutaneous tissue. Specimens were fixed in $10 \%$ neutral-buffered formalin for $24 \mathrm{~h}$ and transferred to $70 \%$ alcohol. Tissues were embedded in paraffin, sectioned at $5 \mu \mathrm{m}$ thickness and stained with hematoxylin and eosin using standard procedures for light microscopy.

\section{Preparation of Platelet Rich Plasma (PRP)}

Equine platelet-rich plasma was prepared by collecting two tubes with $10 \mathrm{ml}$ of equine whole blood in the same day, before the surgical procedures. For the wound-healing study, blood was extracted from each saddle horse. The blood was deposited in two Falcon tubes $(15 \mathrm{ml})$ containing $10 \%$ sodium citrate anticoagulant. The tubes were centrifuged at $300 \mathrm{~g} / 10 \mathrm{~m}$ (Sigma) promoting the separation of the plasma red cells. Plasma with the platelets remained in the superior part and between these two layers exist another one fine and whitened, called intermediate zone, which contained the white cells, mainly leukocytes and the biggest platelets. After that, $500 \mu \mathrm{l}$ of plasma was removed from the superior part of each tube and moved to another tube called tube A. This part was used to obtain the autogenous thrombin. The remaining plasma and also the intermediate zone were transferred to another tube called B to obtain the PRP. This tube was maintained at room temperature. To the tube A was added $300 \mu 1$ of $10 \%$ calcium gluconate, mixed and incubated at $15 \mathrm{~min}$ at $37^{\circ} \mathrm{C}$. Then, both tubes (A and B) were centrifuged at $640 \mathrm{~g} / 10 \mathrm{~m}$ at room temperature. The tube A contained thrombin rich substrate and all the volume was used. The half volume of tube B was discharged and after homogenization, the tube A thrombin was added at 2: 1 ratio ( $2 \mathrm{ml}$ of PRP: $1 \mathrm{ml}$ of thrombin). After $40 \mathrm{~min}$ resting at room temperature the formation of PRP gel was achieved (Figure 1). To count the platelets was used a Neubauer's camara and trypan blue to the better visualization and differentiation of the cells. 


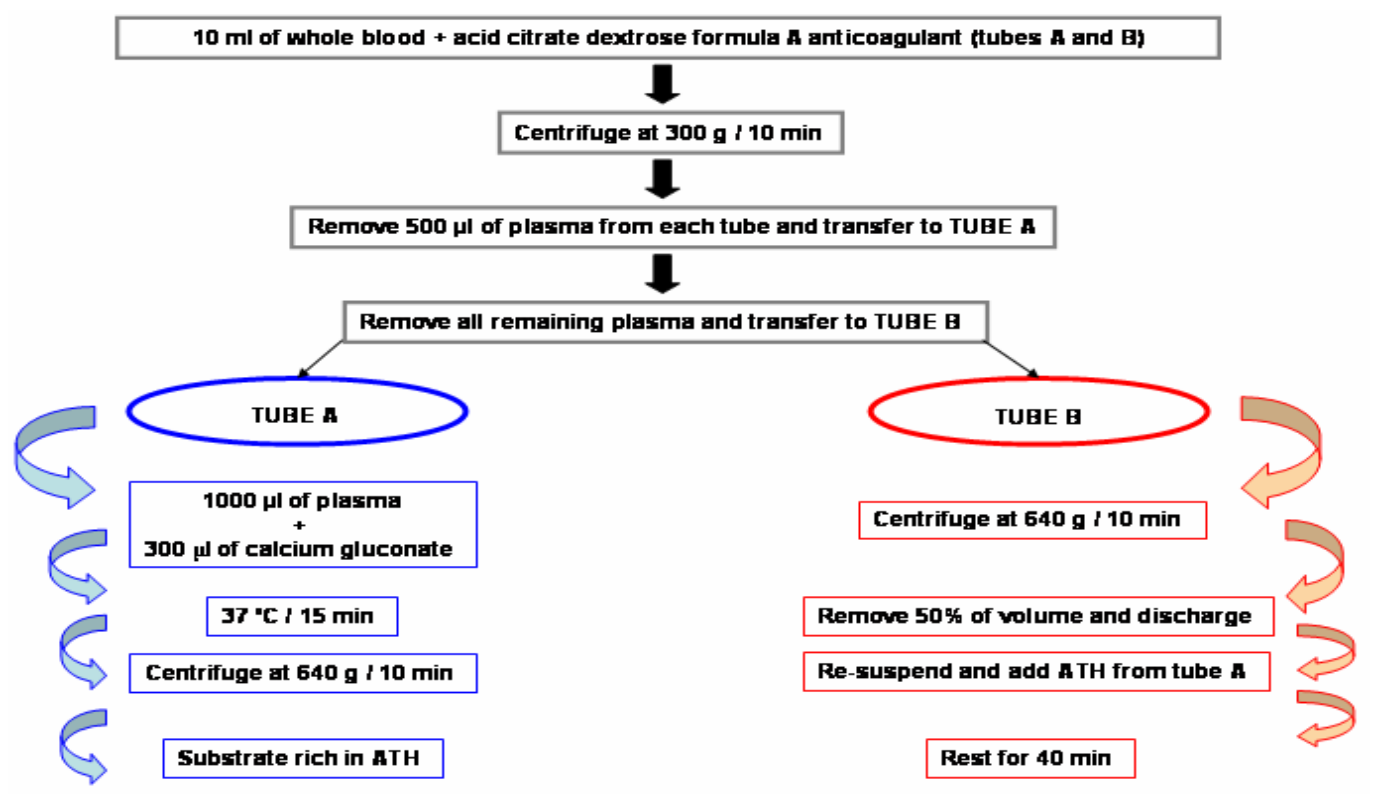

FIGURE 1 - Diagram of the preparation of the autologous thrombin (ATH) and platelets-rich plasma (PRP)

\section{Masson's trichrome stain}

Staining was performed according to revised methods of Masson. Tissues were deparaffinized and rehydrated. Following treatment with Bouin's fixative for $1 \mathrm{~h}$ at $56^{\circ} \mathrm{C}$, the slides were allowed to cool for $10 \mathrm{~min}$. Sections were cleared in running water for $10 \mathrm{~min}$ and rinsed with distilled water. Following a stain in Weigert's iron hematoxylin solution for $10 \mathrm{~min}$, slides were washed in running water for $10 \mathrm{~min}$ and then rinsed in distilled water. Tissues were stained in Biebrich scarlet-acid fuchsin for $15 \mathrm{~min}$, rinsed in distilled water, and exposed to phosphomolybdic-phosphotungstic acid solution for $10 \mathrm{~min}$. Sections were counter-stained in an aniline blue solution for $8 \mathrm{~min}$ and rinsed in distilled water. Following treatment in $1 \%$ acetic water for $4 \mathrm{~min}$, sections were dehydrated, cleared and mounted. Observation and photomicrography were performed during each time at sampled biopsies; by counting of the regenerative cells and tissue repair development, by descriptive analysis.

\section{Results}

No clinical complications were observed in the surgical wound healing in any horse. All wounds presented first intention healing in all horses. The inflammatory process was most intense in the control group than in the PRP gel group. This inflammatory process in the control group decreased after 12 days of the surgical procedures being imperceptible between the groups after the experimental period. The obtention of the autogenous thrombin and the preparation of the PRP gel were simple and without sophisticated materials or instruments, being a fast procedure and with low cost. The value of platelets obtained in the final solution was in average $16 \times 10^{5}$.

In order to evaluate the structural organization of collagen in the dermis of the repaired wound, a Masson's trichrome stain was performed. The microscopical analyses of stained glass microscope slide for the techniques of HE and trichrome in the G1D5, PRP demonstrates epithelial coating represented by keratinized pavimentous stratified epithelium with normal morphology in the three analyzed animals. The dermis shows mononuclear inflammatory infiltrate represented predominantly by macrophages and hyperplasia of the sudoriferous and sebaceous glands. In the same period, the control group demonstrates absent epithelial covering in two of the three analyzed animals. The dermis shows flabby connective tissue with focal areas of mononuclear inflammatory infiltrate. One of the animals presented a little ulcerate area, an exocytosis area and deposit of necrotic debris (Figures 2 and 3 ).

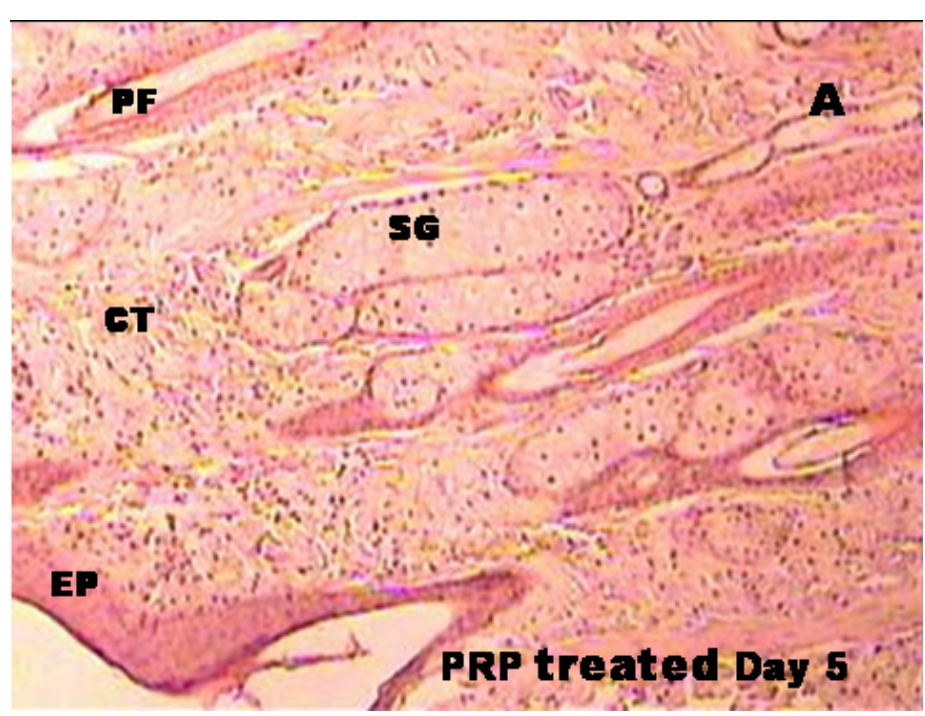

FIGURE 2 - Histological aspect of skin of the PRP group at Day 5 showing the epidermis (EP). The dermis shows connective tissue (CT) with sebaceous glands (SG) and pilous follicles (PF). 5X increase. HE coloration 


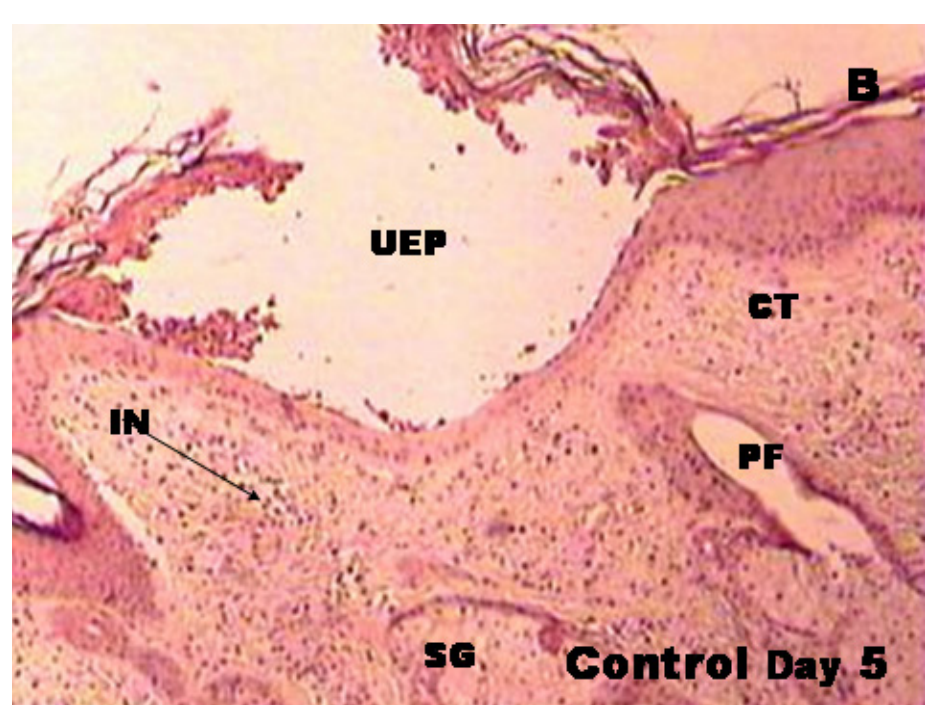

FIGURE 3 - Control group at Day 5 showing ulcerated epidermis (UEP). The dermis shows connective tissue (CT) with sebaceous glands (SG) and pilous follicles (PF) and focal areas of inflammatory process (IN). $5 \mathrm{X}$ increase. HE coloration

The analysis in the G2D15, in the PRP group, demonstrates epithelial tissue with a normal morphology. The dermis shows flabby connective tissue with organized interconnecting collagen fibers running parallel to each other and with thin collagen fibrils and discrete inflammatory infiltrate. The control group of the same period demonstrate preserved epithelial covering also and dermis with flabby connective tissue disorganized with healing area (Figures 4 to 6).

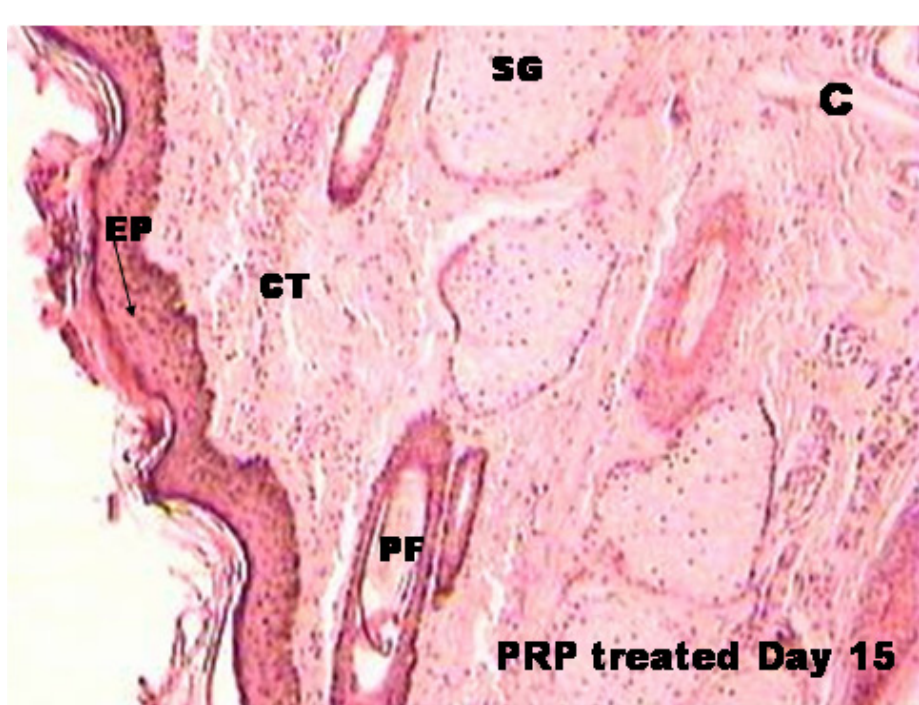

FIGURE 4 - PRP group at Day 15 showing the epidermis (EP). The dermis shows connective tissue (CT) with sebaceous glands (SG) and pilous follicles (PF) and focal areas of inflammatory process (IN). $5 \mathrm{X}$ increase. HE coloration

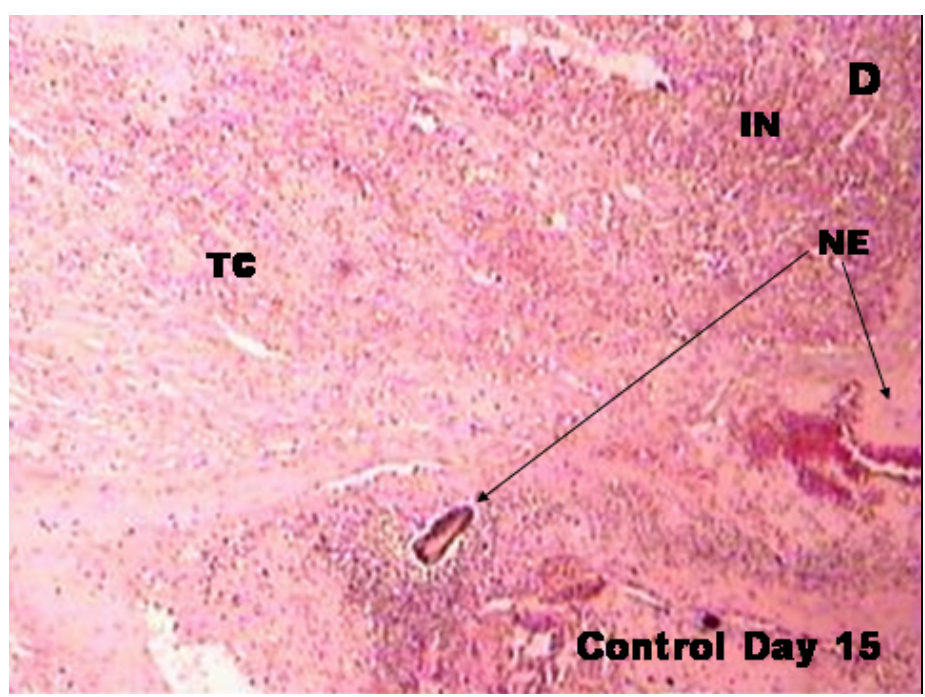

FIGURE 5 - Control group at Day 15. The dermis shows connective tissue (TC) focal areas of inflammatory process (IN) and necrosis (NE). $5 \mathrm{X}$ increase. HE coloration
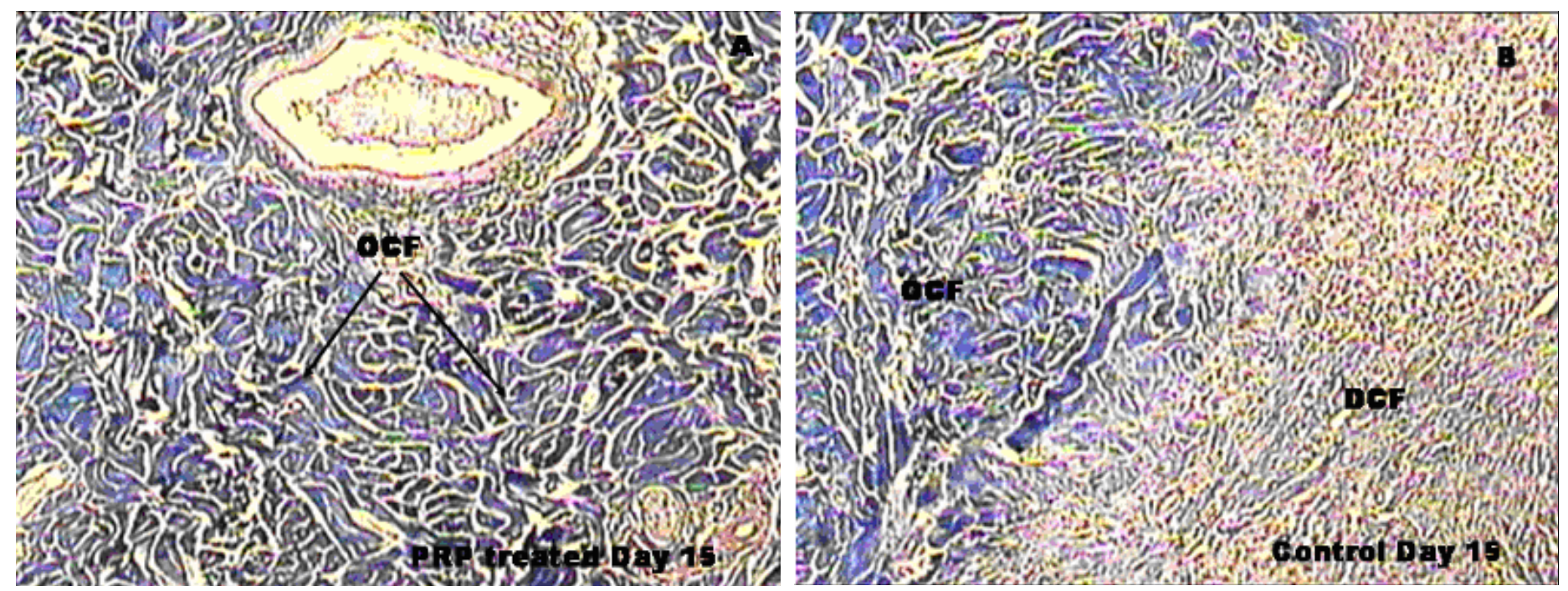

FIGURE 6 - Healing tissues stained with Masson's trichrome. (A) Histological aspect of skin of the PRP Group at Day 15, showing the dermis with connective tissue with organized collagen fibrils (OCF). (B) Control Group at Day 15, showing the dermis with connective tissue with organized collagen fibrils (OCF) and disorganized collagen fibrils (DCF). 5 x magnifications 
In the periods of the 30 and 45 days, several small vessels were apparent in the PRP group, whereas only a few vessels were present in control group (Figures 7 and 8). In the subsequent experimental period (G2D45) were not observed significant microscopic alterations.

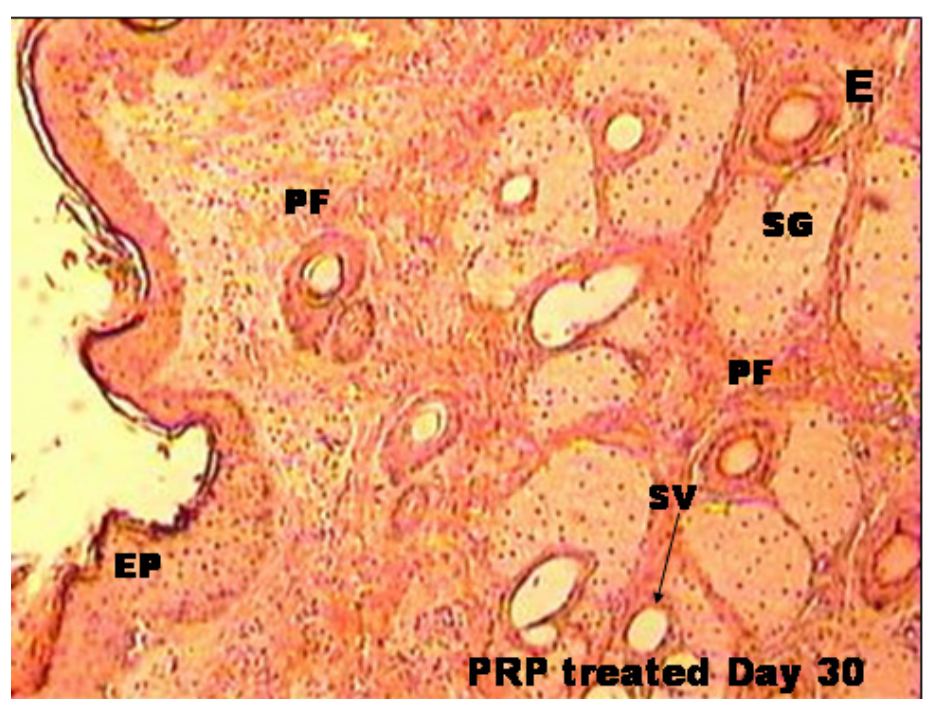

FIGURE 7 - PRP group at Day 30 showing the epidermis (EP). The dermis shows connective tissue (CT) with sebaceous glands (SG) and pilous follicles (PF) and small vessels (SV). 5X increase. HE coloration

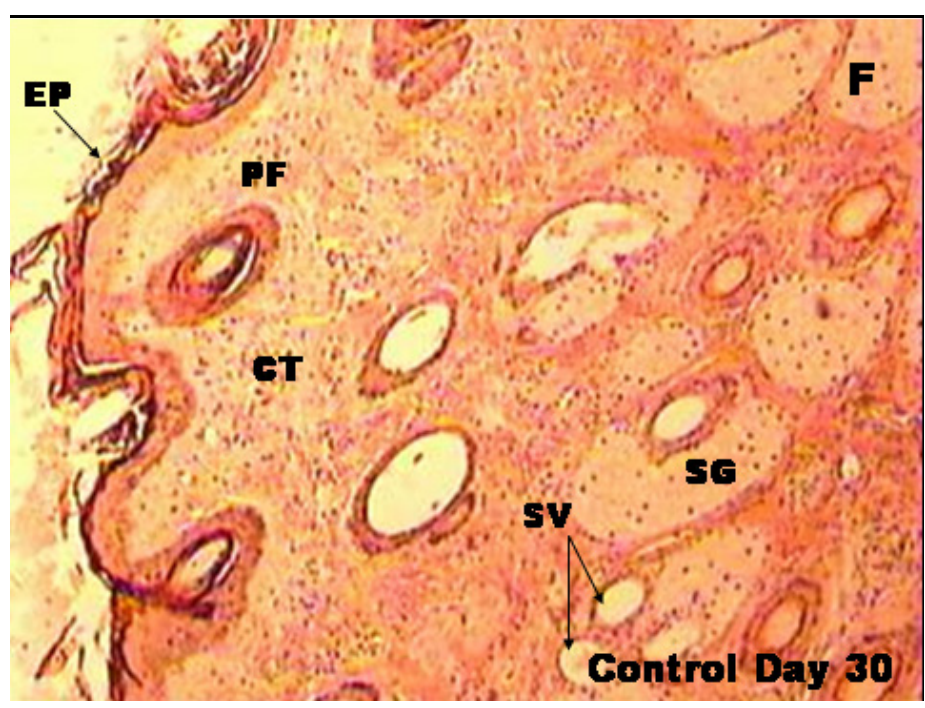

FIGURE 8 - Control group at Day 30 showing the epidermis (EP). The dermis shows connective tissue (CT) with sebaceous glands (SG) and pilous follicles (PF) and small vessels (SV). $5 \mathrm{x}$ magnifications

\section{Discussion}

Our objective was to develop a simple and no onerous technique of PRP autogenous gel obtention and to analyze if the addition of this product speeds up the healing process in sequential biopsies from equine surgical wounds. We developed a wound healant composed of concentrated PRP, thrombin and calcium gluconate that is delivered as a topical or subcutaneous gel to surgical or traumatic wounds. The first forms of autologous PRP obtention for use in human surgeries used autotranfusion machines to make the cellular separation of the blood that circulated for it proceeding from a deep placed venous catheter in the patient during the surgery. It was necessary $400-450 \mathrm{~mL}$ of blood and a specialized technician to operate this equipment, what limited to a chirurgic centre and represented a higher morbidity to the patient ${ }^{10}$. The attainment of PRP gel through conventional automatized kits possesses a very high cost. The possibility of the obtention of PRP gel with lower costs, using a conventional centrifuge, generated some protocols that even so they are more laborious and need specialized personal, they diminished the cost in 10 times and are made in simpler environments ${ }^{11}$. We proposed in this study a preparation of the equine autologous PRP gel with a simpler and easier technique and a fast extraction of the PRP. Its preparation delays about $45 \mathrm{~min}$, after the collection of the blood. With this protocol we were able to reach a concentration at least 4 times in superior average to the one of the sample of blood. These results are greater than in other studies, which were not able to obtain an increase of 2 times the platelet concentration of the patient ${ }^{5}$. In our protocol with the used volume the autologous thrombin obtained was enough for the acceleration and formation of the PRP gel.

The PRP gel is a product that induces a healing acceleration of difficult-to-heal wounds4. The initial phase of the healing is mediated by growth factors secreted by the platelets. The platelets were activated with thrombin, a naturally occurring platelet activator that promotes wound healing. This fact induces a decreased wound size by $60 \%$, increased the fibroblast to macrophage ratio and increased proliferating fibroblast $150 \%{ }^{12}$. This activation of platelets also causes release of VEGF a mediator of angiogenesis that stimulates endothelial cell proliferation ${ }^{13}$. EGF is released by platelets and is chemostactic for fibroblast and topical application accelerated the rate of epidermal regeneration and increased wound tensile strength ${ }^{14}$. PDGF is released by $\alpha$-granules in activated platelets, which are the largest source of PDGF in the body ${ }^{8}$. PDGF induces fibroblast and smooth muscle cell migration and proliferation and is a chemo attractant for neutrophils and monocytes ${ }^{15}$. The transforming growth factors (TGF: TGF- 31 and TGF- $\beta 2$ ) activates fibroblasts for pre-collagen formation, that induces in the deposition of collagen and healing wound. PDGF associated or not with TGF, increased the tissue vascularisation, promote fibroblast proliferation, increased collagen formation and stimulate the production of granulation tissue and wound tensile strength when applied locally in animal models ${ }^{16}$. All this factors accelerated the healing, favouring the integration of bone, cutaneous, cartilaginous or fat cells grafts. An increased number of fibroblasts in our PRP-gel wounds may help explain the increased collagen and repair in the dermis following the treatment.

Concentration and activation of platelets into a PRP and topical application of this PRP as a gel is shown in this experiment to be an effective method for replacing essential growth factors. In this study, we did not analyzed the transforming growth factors but in another study the concentration TGF- $\beta$ was significantly increased in the PRP $(7481 \mathrm{pg} / \mathrm{ml})^{8}$. TGF- $\beta$ released from blood platelets at sites of tissue damage is physiologically targeted to intervene in wound healing ${ }^{17}$. TGF- $\beta$ increases granulation tissue, collagen formation, and wound tensile strength when applied locally in animal models ${ }^{16}$. 


\section{Conclusion}

The PRP gel and GF obtention can be done in a more economical form and in places without many resources but that usually make use of a centrifuge and common materials in hospital environments as syringes, needles and tubes for blood collection. The use of PRP gel as an improved therapy for surgical or non-healing wounds in equine and in immunocompromised, diabetic or elderly individuals could provide quality healing of acute wounds that would be of significant personal, economic and social advantage.

\section{References}

1. Bertone AL. Management of exuberant granulation tissue. Vet Clin North Am Equine Pract. 1989;5:551-62.

2. Fitch RB, Swaim SF. The role of epithelization in wound healing. Comp Cont Edu Pract Vet. 1995; 17:167-77.

3. Dugrillon A, Kluter H. Current use of platelet concentrates for topical application in tissue repair. Ther Transfus Med. 2002;29:67-70.

4. Robson MC. The role of growth factors in the healing of chronic wounds. Wound Rep Regenerat. 1997;5:12-7.

5. Marx RE. Platelet-rich plasma: evidence to support its use. J Oral Maxillofacial Surg. 2004;62:489-96.

6. Harrison P, Cramer EM. Platelet ?-granules. Blood Rev. 1996;7:52-62.

7. Dyson M. Advances in wound healing physiology: the comparative perspective. Vet Dermatol. 1997;8:227-33.

8. Carter AC, Jolly DG, Worden CE, Hendren DG, Kane CJM. Platelet-rich plasma gel promotes differentiation and regeneration during equine wound healing. Exp Mol Pathol. 2003;74:244-55.

9. Bennett NT, Schultz GS. Growth factors and wound healing. Part II. Role in normal and chronic wound healing. Am J Surg. 1993;166:74-81.
10. Kevy SV, Jacobson MS. Comparison of methods for point of care preparation of autologous platelet gel. J Extra Corpor Technol. 2004;36:28-35.

11. Vendramin FS, Franco D, Nogueira CM, Pereira MS, Franco TR. Platelet-rich plasma and growth factors: processing technique and application in plastic surgery. Rev Col Bras Cir. 2006;33:24-8.

12. Strukova SM, Dugina TN, Chistov IV, Lange M, Markvicheva EA, Kuptsovas S, Zubov VP, Glusa E. Immobilized thrombin receptor agonist peptide accelerates wound healing in mice. Clin Appl Thromb Hemost. 2001;7:325-9.

13. Kliche S, Waltenberg J. VEGF receptor signaling and endothelial function. IUBMB Life. 2001;52,61-6.

14. Adelmann-Grill BC, Wach F, Cully Z, Hein R, Kreig T. Chemotactic migration of normal dermal fibroblasts towards epidermal growth factor and its modulation by platelet-derived growth factor and transforming growth factor-beta. J Cell Biol. 1990;51:322-6.

15. Hosgood G. Wound healing: the role of platelet-derived growth factor and transforming growth factor beta. Vet Surg. 1993;6:490-5.

16. Assoian RK, Komoriya A, Meyers CA, Miller DM, Sporn MB. Transforming growth factor-beta in humans platelets. J Biol Chem. 1983;258:7155-60.

17. Ashcroft GS, Yang X, Glick AB, Weinstein M, Letterio JL, Mizel DE, Anzano M, Greenwell-Wild T, Wahl SM, Deng C, Roberts AB. Mice lacking Smad3 show accelerated wound healing and an impaired local inflammatory response. Nat Cell Biol. 1999;1:260-6.

\section{Acknowledgement}

We are grateful to Dr. Ricardo A. A. de Lemos for histological expertise, and to the veterinary assistants who assisted with biopsy collection.

Conflict of interest: none

Financial source: none

\section{Correspondence:}

Rafael DeRossi

Faculty of Veterinary Medicine and Animal Science

Federal University of Mato Grosso do Sul

79070-900 Caixa Postal 549P, Mato Grosso Sul - MS Brazil

derossi@nin.ufms.br

Received: January 20, 2009

Review: March 18, 2009

Accepted: April 15, 2009

\section{How to cite this article}

DeRossi R, Coelho ACAO, Mello GS, Frazílio FO, Leal CRB, Facco GG, Brum KB. Effects of platelet-rich plasma gel on skin healing in surgical wound in horses. Acta Cir Bras. [serial on the Internet] 2009 July-Aug;24(4). Available from URL: http://www.scielo.br/acb 